Covered in: CrossRef; RePEC; CEEOL; Google Scholar.

2019, Volume 1, Issue 1, pages: 64-69 | doi: 10.18662/jmsw/07

\section{Book Review on "Enciclopedia curiozitatilor. Trecut si prezent", authored by Ion Xenofontov, LUMEN Publishing House}

\section{Antonio SANDU1}

${ }_{1}$ Professor PhD, Stefan cel Mare University of Suceava, Romania, antonio1907@yahoo.com
Abstract: Within the volume Enciclopedia curiozităților. Trecut şi prezent (Encyclopaedia of Curiosities. Past and present), author Ion Xenofontov, published by the LUMEN Publishing House in Iaşi, Romania, under the auspices of the Scientific Library (Institute) Andrei Lupan, the Center for Encyclopaedic Research in the Republic of Moldova, a volume that is the subject of the present review, topics related to the holy places, personalities, nature, localities, ethnic imagery, education, spaces and memory, violence, historical borders and leisure - all with reference to objectives in the Republic of Moldova, but also partially with references to such objectives in Romania.

Keywords: Ion Xenofontov; Encyclopaedia of Curiosities; Republic of Moldova.

How to cite: Sandu, A. (2019). Book review on "Enciclopedia curiozitatilor. Trecut si prezent", authored by Ion XENOFONTOV, LUMEN Publishing House. Joumal of Mediation \& Social Welfare, 1(1), 64-69. doi:10.18662/jmsw/07 


\section{Introduction}

The encyclopaedic literature of the Republic of Moldova was enriched in 2019 with a new volume from the Encyclopaedia of Curiosities series, more precisely with the volume Past and Present, which is the second volume in this series, published by Ion Xenofontov within the LUMEN Publishing House in Romania.

The volume appears under the prestigious aegis of the Scientific Library (Institute) Andrei Lupan, Center for Encyclopaedic Research in the Republic of Moldova. Within this volume, topics dealing with holy places, personalities, nature, localities, ethnic imagery, education, spaces and memory, violence, historical borders and leisure - all with reference to objectives in the Republic of Moldova, but also with references to similar objectives in Romania, as discussed.

We warmly recommend reading this volume to all those interested in the history, culture and civilization of this East-European country and, in particular, the Romanian dimension of Moldovan spirituality and culture, but also of the place of Moldova between Prut and Dniester - Bessarabia - in culture and spirituality Romanian, which looks beyond the historical or political borders that geographically separate the two countries, Romania and the Republic of Moldova.

Without following the chronology of the chapters established by the author in this volume, we will draw attention to a few topics that have aroused our interest in its course, without having to pretend to exhaust the rich ideographic content of this encyclopaedia.

\section{Ethnic imagery}

The issue of ethnic imagery is a key to understanding the cultural identity of the various minorities but also of the majority inhabitants of regions with multicultural specificity. This theme is by definition one of overwhelming importance for the Republic of Moldova, where, together with the population of Romanian origin, minorities like the Russian or Gagauzian population live, and the problem of harmonious coexistence between them can be a necessary element for social and political stability and respectively economic, social and cultural development of the Republic.

The Transnistrian conflict, probably artificially maintained by interest groups in Moldova and beyond, puts serious limits on the development of the statehood of Moldova. Without being completely an interethnic conflict, but rather a politically manipulated one, interethnic relations are important 
for mitigating the risk of escalating this conflict, especially against the backdrop of crises caused by Russia's involvement in the so-called selfdetermination of the Russian-speaking population in different regions of the Ukraine, neighbour to Moldova, when Russia has, since the cold war, dislocated a strong armed force stationed in Transnistria, a territory that is part of the Republic of Moldova but has declared its independence unilaterally.

The observations regarding the Transnistrian conflict belong to us and not to the author of the Encyclopaedia, but we consider it a good starting point in approaching the problem of identity imagery, which is the subject of a chapter within this Encyclopaedia.

The chapter dedicated to the imagery of interethnic relations opens, not coincidentally, with an analysis of the history of German ethnic groups in Romania, which we consider a subtle statement of the author's adherence to the idea of the spiritual and cultural unity of the Romanian space regardless of the state borders. The German minority in Romania, geographically located in various regions of Transylvania, is presented as an example of an ethnic community that makes a special contribution to the development of the Romanian culture and spirituality, even though there were temporary differences between the German and Romanian ethnic groups but also between each other the communist government of Romania (1975-1988), for example, and Romanian citizens of German ethnic origin. The author shows that between 1975 and 1988, 170 thousand ethnic Germans from Romania emigrated to Germany, the Federal Republic of Germany paying to Romania 700 million German marks, an amount between 4000 - 5000 marks for each ethnic German who was allowed to emigrate. In 1989, at the fall of the communist regime in Romania, there were 250,000 people who declared themselves of German ethnic origin. Currently, 35,000 ethnic Germans live in Romania.

The plea for multiculturalism, especially in the Republic of Moldova, is made by the author against the background of his statement that, although in the Republic of Moldova, several ethnic groups live, "in general, they live in an alterity: they do not know each other in complexity."'Xenofontov, 2019, p. 144).

The "Republican Festival of the Ethnicities" is presented as such, as an instrument of mutual knowledge of the cultural and material values specific to the various ethno-cultural communities living in the territory of the Republic of Moldova. The majority population of the Republic, the Moldovan one presented its stand at the $15^{\text {th }}$ edition of the 2016 Republican Festival of the Ethnicities - where representatives of 14 different ethnic 
groups living on the territory of Moldova participated - under the emblems of the European Union. The Russian community from the Republic of Moldova has chosen to represent this festival through the largest exhibition area, while the Russian community of old rites - Lipovan - emphasized religiousness, spirituality and creation. With a fine irony, the author criticizes Moldovan politicians, who "this time did not miss the opportunity to promote their image, organizing public meetings" (Xenofontov, 2019, p.147), thus politicizing the event and, implicitly, the subject matter of interethnic relations in the Republic of Moldova. An important minority in the Republic of Moldova is that of the Gagauzians, which at the 2004 census numbered 147.5 thousand ethnic groups $-4.4 \%$ of the population of the Republic. Since 1994, the Autonomous Territorial Unit with special status Gagauzia operates, comprising 32 localities. Throughout history, says the author, "the Gagauzians have identified themselves as Bulgarians, Greeks, Arduians" (Xenofontov, 2019, p. 150). They speak a language of Turkic origin, close to the Turkish language, they have adopted the orthodox religion, but God is called Allah or Boji-Boje.

The author of the Encyclopaedia draws attention to the fact that the ethnic identity of the Gagauzians is little known by the other inhabitants of the Republic of Moldova, the Gagauzians being considered aggressive and possessing white weapons, which is not the case in reality. Also, it seems that some people in the public services of the Republic of Moldova consider the Gagauz people as actually Turks and Muslims, although their spirituality is based on the Orthodox Christian faith.

\section{Other topics of interest in the volume}

The first theme addressed in the volume is the holy places of Moldova. Within this chapter are presented the Armenian Apostolic Church "The Assumption of the Virgin Mary" in Chisinau (Xenofontov, 2019, p. 15), the Roman-Catholic Church "The Assumption of the Virgin Mary" in Orhei (Xenofontov, 2019, p. 22), the Cathedral "Saint Dumitru " from Orhei (Xenofontov, 2019, p. 30).

Among the personalities from the Republic of Moldova presented in the volume we mention:

- Academician Alexandru Ciubotaru (1932-2017)

- Academician Vitalie Postolati

- Academician Valeriu Rudic

- The composer- academician Eugen Doga

- Double Olympic champion Nicolae Juravschi 
- The encyclopaedist Nicolae Milescu

- Military priest Alexie Mateevici

- Writer Nikolai Vasilievici Gogol

- Sportsman and farmer Dumitru Tiron

- Stephen the Great and Holy

A final mention regarding a topic approached within the volume, that of the execution of the dictatorial couple Nicolae and Elena Ceausescu (Xenofontov, 2019, p. 225) emphasizes once again the author's intention to emphasize the spiritual unity of the Romanian space and, once with it, assuming history, including that of the communist period, in a tradition of a true historian who sees events without hatred and bias and who finds the right measure somewhat in presenting history but also in interpreting the present.

\section{Instead of conclusions}

The author of this book, the researcher Ion Xenofontov, historian at the Andrei Lupan Institute, the Encyclopaedic Research Centre of the Republic of Moldova and Doctoral Lecturer at the State University of the Republic of Moldova, enjoys a wide national and international recognition, being one of the road blowers in field of encyclopaedic research in the Republic of Moldova.

The encyclopedia of curiosities, located in the second volume, represents a cultural and scientific initiative as well, which is intended to be a revival of encyclopaedism in the Romanian cultural space. Polarized by the interest in novelty at any price, the Romanian scientific world passes in the second plane the idea of popularizing knowledge and implicitly the encyclopaedic studies that aim to make known to the general public historical, social, cultural phenomena, as they appear through the prism of the documents analysed by the researcher.

Encyclopaedic research is not generally addressed to a limited circle of specialists, but is intended to be accessible to a broader public, interested in the areas presented and who wish to broaden their general culture with basic information from as many fields.

We welcome the initiative of Mr. Ion Xenofontov and implicitly that of the LUMEN Publishing House to publish this series of the Encyclopaedia of Curiosities, which has come to reopen the public's curiosity for encyclopaedic knowledge and, thus, widening the horizon of knowing each one of us. 
We warmly recommend the volume Encyclopaedia of Curiosities. Past and present, as well as the entire series of the Encyclopaedia of curiosities of all those interested in Romanian spirituality, regardless of whether this spirituality was born in Romania or in Bessarabia (Republic of Moldova).

\section{References}

Xenofontov, I. V. (2019). Enciclopedia curiozităților. Trecut şi prez̧ent. Iaşi, România: LUMEN. 